\title{
顎下腺唾石に合併した扁平上皮癌例
}

\author{
朝日 淳仁・野中聡・荻野武・吉野 和美 \\ 石田 芳也・今田 正信・林達哉・原渕 保明
}

\section{A Case of Squamous Cell Carcinoma with Sialolithiasis of the Submandibular Gland}

\author{
Atsuyoshi Asahi, Satoshi Nonaka, Takeshi Ogino, Kazumi Yoshino, \\ Yoshiya Ishida, Masanobu Imada, Tatsuya Hayashi and Yasuaki Harabuchi \\ (Asahikawa Medical College)
}

We experienced a case of squamous cell carcinoma with sialolithiasis by metaplasia in the duct of a submandidular gland. A 58-year-old man was referred to our hospital to treat a mass in the oral cavity. There was a sialolithiasis in the proximal part of Wharton's duct. So, we removed the left submandibular gland. Metaplastic change was found in Wharton's duct with calculi, and, in the central part of the metaplasia, well differented squamous cell carcinoma was located. Neck lymph nodes were not swollen, so no further treatment was taken. There was no sign of reccurence. We studied the metaplasia rate in Wharton's duct in sialolithiasis patients who had been treated by submandibular gland removal in our hospital. About $90 \%$ of patients' metaplasia were found in areas with calculi. We thought that metaplasia in the duct was highly correlated with calculi, and that squamous cell carcinoma might occur on the basis of metaplasia.

Key words : squamous cell carcinoma, sialolithiasis of submandibular glands, metaplasia, calculi

はじめに

唾石症は $80 \%$ が顎下腺内および顎下腺導管（ワルトン 管）に発生する良性疾患である，その治療法は唾石の存 在部位に応じて口腔内粘膜よりワルトン管を切開する口 内法や顎下腺全摘術が選択される. 今回われわれは, 顎 下腺導管移行部唾石症に合併した導管上皮癌症例を経験 したため, 当科の過去の顎下腺内唾石症患者に対する組 織学的検討と文献的考察を加えて報告する.

\section{症例}

症例 : 58 歳, 男性.

主訴：口腔内腫瘤.

現病歴: 2002 年 10 月頃より口腔内の腫瘤を自覚し, 徐々に増大してきたため 2003 年 4 月 25 日当科初診した.
既往歴：大腸ポリープ.

家族歴：特記すべき事項なし。

初診時所見: 左口腔底部に小豆大の硬い腫瘤を触知し, その部位は双手診にて左顎下腺移行部に一致していた。 左顎下腺の腫脹, 頸部リンパ節の腫脹は認めなかった。 その他, 耳鼻咽喉科領域に明らかな異常所見を認めな かった。

単純 $\mathrm{X}$ 線検查所見：左顎下腺部に円形の石灰化像を認 めた（図 1).

$\mathrm{CT}$ 検査所見: 左顎下腺の腺管移行部に唾石の陰影を認 めた。顎下腺に異常は認めなかった。頸部リンパ節の腫 大も認めなかった（図 2).

以上の所見から左顎下腺移行部唾石症と診断され, 2003 年 7 月 28 日に全身麻酔下に左顎下腺全摘術を施行 


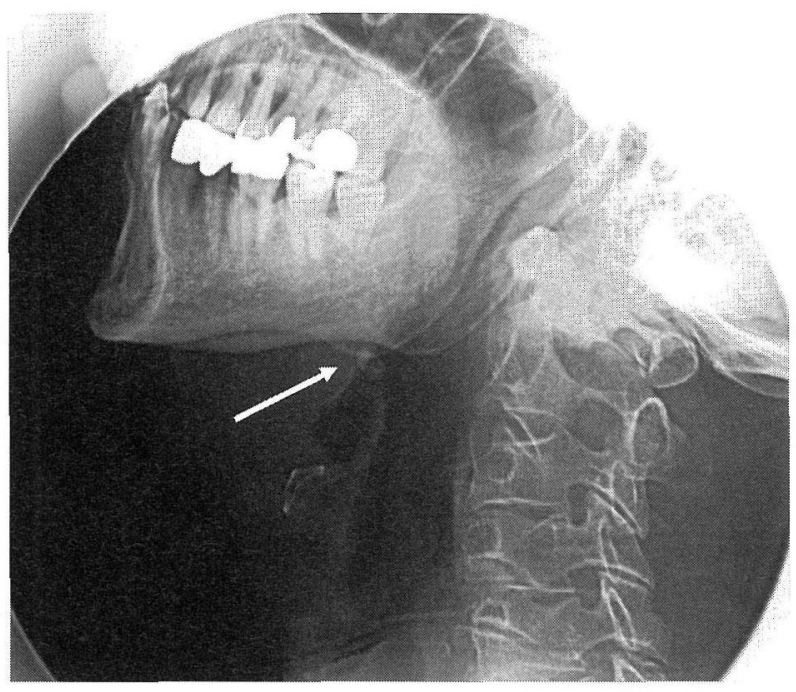

図 1 矢印の部位に単純 Xp にて石灰化病変を認めた。

した。癒着などの所見は認めず，周辺のリンパ節も認め られなかった。

摘出物所見：腺管移行部に $8 \times 5 \times 5 \mathrm{~mm}$ 大の唾石が嵌 頓して存在していた，摘出した顎下腺に肉眼的な異常所 見核めなかった。

病理組織学的所見：唾石が存在し拡張した導管上皮に 扁平上皮化生を認め，その一部に大部分が粘膜内病変で 一部間質に浸潤する高分化型扁平上皮癌を認めた(図3). 導管断端および唾液腺剥離面に腫瘍の露出は認められな

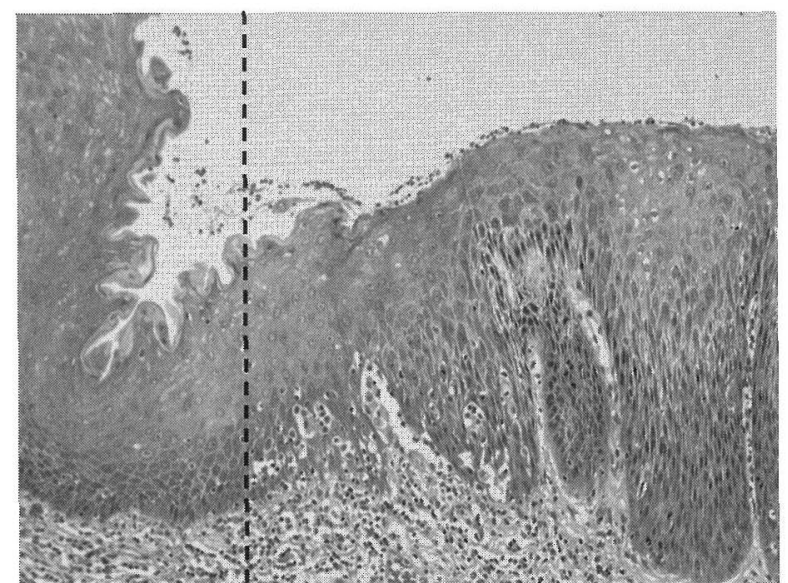

a

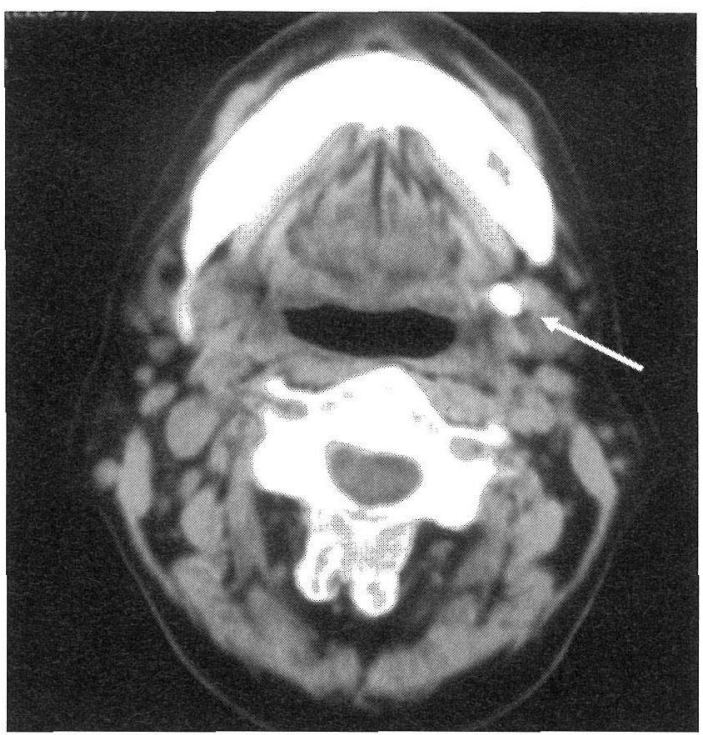

図 2 矢印の部位に CT 上石灰化病変を認めた。

かった.また，導管外への腫瘍浸潤も認められなかった。 扁平上皮化生を発生母地として癌化した可能性が示唆さ れた。手術操作により扁平上皮癌の切除は完全であった と判断されたので，追加の治療は行わず現在経過観察中 である。術後 1 年 6 力を経過しているが再発を認めて いない.

顎下腺唾石症における導管上皮の扁平上皮化生の頻 度：顎下腺唾石症患者の導管上皮において扁平上皮化生

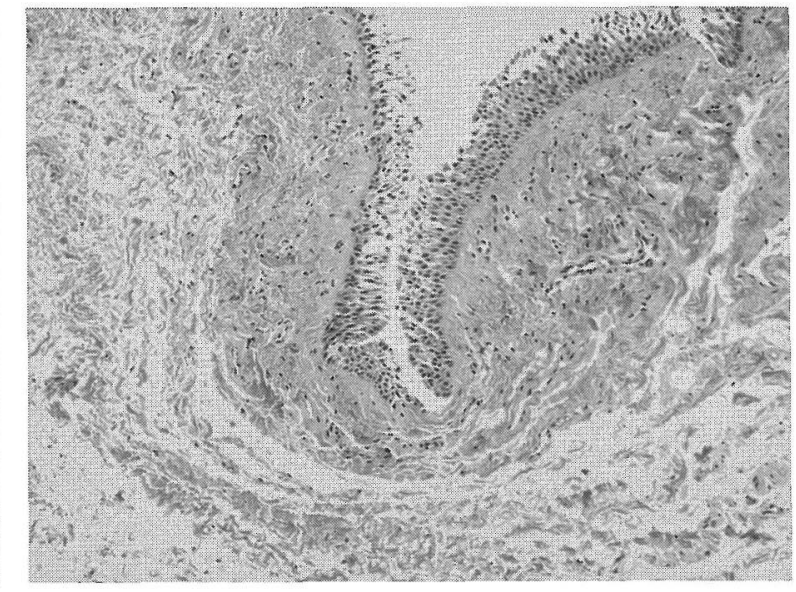

b

図 3 病理組織学的所見 (HE 染色, 100 倍)

$\mathrm{a}$ ：点線より左方が扁平上皮化生，右方が扁平上皮癌 $b$ ：正常導管部分 
表 1 腺管移行部唾石症にて顎下腺摘出術施行症例の検討

\begin{tabular}{|c|c|c|c|}
\hline 症例 & 年齢, 性 & 有病期間 & 扁平上皮化生 \\
\hline 1 & 31 男 & 2Mo & 有 \\
\hline 2 & 26 女 & 1Mo & 有 \\
\hline 3 & 39 女 & 1Mo & 有 \\
\hline 4 & 58 男 & 8Mo & 有 \\
\hline 5 & 46 男 & $6 \mathrm{Mo}$ & 有 \\
\hline 6 & 71 男 & 4Mo & 有 \\
\hline 7 & 48 男 & $5 \mathrm{Mo}$ & 有 \\
\hline 8 & 70 男 & $6 \mathrm{Mo}$ & 有 \\
\hline 9 & 29 女 & 3Mo & 否 \\
\hline 10 & 45 男 & $1 \mathrm{Mo}$ & 有 \\
\hline 11 & 26 女 & 16Mo & 有 \\
\hline 12 & 58 男 & $2 \mathrm{Mo}$ & 有 \\
\hline 13 & 37 男 & 252Mo & 否 \\
\hline 14 & 59 男 & 不明 & 有 \\
\hline 15 & 27 男 & 不明 & 有 \\
\hline 16 & 53 男 & 不明 & 有 \\
\hline 17 & 42 男 & 不明 & 有 \\
\hline 18 & 56 男 & 不明 & 有 \\
\hline 計 & & & $16 / 18$ \\
\hline
\end{tabular}

がどのような頻度で発生するのかを検討するため, 当院 において過去に顎下腺全摘術を施行され，唾石陥頓部位 が明らかであった18例の顎下腺唾石症患者の病理組織標 本を再検討した（表 1)。罹病期間は 1 力月から 252 力月 であった. 18 例中 16 例（89\%）に唾石が存在していた 部位と一致して導管上皮の扁平上皮化生が認められた。 扁平上皮化生が認められなかった 2 例の罹病期間はそれ ぞれ，3カ月，252カ月であった。

\section{考察}

顎下腺唾石症は比較的多い疾患であるが，扁平上皮癌 を合併した症例の報告は渉編しえる限りにおいては1965 年に Shanon ら ${ }^{1)}$ によって報告された 1 例のみである。そ の症例は35年間にも渡ってワルトン管に唾石が存在した という持続的刺激により, 扁平上皮化生から扁平上皮癌 が誘発された可能性を示唆するものであった. 今回の症 例では罹病期間は約 8 力 月 Shanon ら ${ }^{11}$ の報告と比べる と短かったが，唾石の存在した部位に一致して導管上皮 に扁平上皮化生が認められたこと，さらに扁平上皮化生 部位に連続して扁平上皮癌が存在したことを考慮すると
同様の機序が扁平上皮癌の発生に関与したものと推察さ れる.

一般的に扁平上皮化生は子宮頸癌, 肺門型肺癌, 上顎 癌2)に括いては前癌病変と考えられている。それらの発 生にはそれぞれ，エストロゲン，喫煙，慢性副鼻腔炎の 影響を受けるといわれている。 また，結石が管腔器官に 陥頓することによって癌が合併した症例の報告として は，腎尿管結石に合併した腎孟扁平上皮癌症例3) や，胆 石に合併した胆囊扁平上皮癌症例4) などがある，尿路上 皮に原発する扁平上皮癌の発生因子としては局所の慢性 刺激あるいは炎症が扁平上皮化生をもたらし，ひいては 扁平上皮癌を誘発すると考えられている。

われわれの経験した症例は病状期間が 8力月と短いに もかかわらず，扁平上皮化生を基盤とした扁平上皮癌を 認めたことから，たとえ唾石による刺激期間が短くても 導管上皮に扁平上皮癌が発生する可能性はあるものと考 えられた。 また，摘出物の病理組織検查においては少な くとも睡石の存在していた導管上皮の部位は十分に鏡検 し, 扁平上皮化生や扁平上皮癌組織の有無を検索する必 要があると考えられた。

本論文の要旨は第 14 回日本頭頸部外科学会 (平成 16 年 1 月, 東京）にて発表した.

\section{参考文献}

1) Shanon $E$ and Kessler $E$ : Squamous cell carcinoma of Wharton's duct. A case of long-standing calculus. Arch Otolaryngol $82: 633 \sim 634,1965$.

2）小川晃弘：鼻・副鼻腔癌の病理学的検討; 特に化生及び異

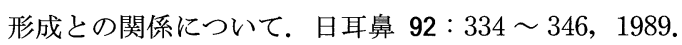

3）丸山 聡, 原田健一, 武中 篤: 結石による膿腎症を契機 として発見された腎孟扁平上皮癌の一例. 西日泌尿 $64: 267$ $\sim 278,2002$.

4）水島睦枝, 佐藤博道, 伊藤慈秀: 胆囊の扁平上皮癌; 4 症 例報告と本邦 13 剖検例の臨床病理学的研究. 胆と膵 5 : $1311 \sim 1318,1984$.

原稿受付：平成17年12月 6 日 原稿採択：平成18年 1 月 18 日 別刷請求先 : 朝日淳仁

干 078-8510 旭川市緑が丘東 2 条 1-1-1 旭川医科大学耳鼻咽喉科・頭頸部外科学教室 